УДК 616.381-002.1-031.81-07-08-035 DOI: $10.24061 / 1727-0847.18 .2 .2019 .3$

\title{
А.Ф. Гринчук
}

Кафедра хірургії № 1(зав. - проф. І.Ю. Полянський) Вищого державного навчального закладу Украӥни «Буковинський державний медичний університет», Чернівиі

\section{КОМПЛЕКСНИЙ ПІДХІ ДО ДІАГНОСТИКИ ТА ЛІКУВАННЯ ПОШИРЕНОГО ГОСТРОГО ПЕРИТОНІТУ}

\begin{abstract}
Резюме. У статті наведені дані щодо комплексної діагностики і прогнозування ускладнень у разі гострого перитоніту, а також метод санації очеревинної порожнини, засновані на застосуванні напрацьованих методів. Показано, що визначення співвідношення ширини зони розсіювання зміненою і незміненою очеревиною лазерного променя може слугувати об'єктивним критерієм діагностики поширеності перитоніту. Наведена шкала для прогнозування ускладнень за гострого перитоніту, яка відрізняється простотою і значною інформативністю та дає підставу обгрунтовано виділяти групи низького, середнього і високого ризику виникнення післяопераційних ускладнень, а проведення прогнозування в два етапи дає змогу диференційовано застосовувати профілактичні заходи впродовж проведення передопераційного підготування, субопераційно і протягом післяопераційного лікування. Описаний метод санації, який полягає у введенні в очеревинну порожнину багатопросвітного санаційно-дренажного пристрою, що дає змогу значно покращити лікування хворих на гострий перитоніт.
\end{abstract}

Ключові слова: гострий перитоніт; діагностика; прогнозування ускладнень; санація; дренажний пристрій.

Незважаючи на застосування нових прогресивних методик, наслідки лікування гострого перитоніту (ГП) не завжди є задовільними [1]. Серед причин цього $\epsilon$, зокрема, відсутність єдиних визнаних підходів до діагностики і вибору обсягу лікування [1-4].

Мета дослідження: напрацювати комплексний підхід до діагностики та лікування поширеного гострого перитоніту

Матеріал і методи. 20 білих нелінійних щурів з моделями асептичного і септичного перитоніту. Медичні карти 169 хворих на ГП, віком від 17 до 84 років. Місиевий ГП діагностований у 45 хворих, дифузний - у 53, розлитий - у 57, загальний - у 13 хворих. У 123 хворих діагностовано супровідні захворювання. У 79 паџієнтів були післяопераційні ускладнення: 24 випадки запалення $i$ нагноєння рани, 5 - евентерацій, 14 -інтраабдомінальних інфільтратів і абсиесів, 18 -неспроможності кишкових швів, 18 - триваючого перитоніту. Померли 39 хворих. Аналізували клінічні та антропометричні дані, результати лабораторних методів, параметри Мангаймського перитонітного індексу (МПI) [6], класу коморбідності (КК) [7], вік. Почиреність перитоніту визначали за шириною зони розсіювання лазерного променя (ШЗРЛП) парієтальною очеревиною (патент на корисну модель №125342 UА, бюл. № 9 від 10.05.2018). Для прогнозування можливих ускладнень застосовували розроблену шкалу [8], згідно з якою прогнозування проводять у два етапи - до ma під час операції. У 26 хворих на гострий перитоніт використали запрограмовані повторні санації черевної порожнини. У 16 з них використаний розроблений метод пролонгованої саначії через багатопросвітні дренажні конструкиії (nатент на корисну модель № 79651 UА, бюл. № 8 віd 16.11.12).

Результати досліджень та їх обговорення: За сумою пунктів, визначеною згідно з прогностичною шкалою, хворих попередньо розподіляємо на групи звичайного (2-4 пункти), збільшеного (5-7 пунктів), середнього (8-9 пунктів) і високого (10 і більше пунктів) ризику. Це дає змогу застосовувати необхідні профілактичні заходи вже на етапі передопераційного підготування.

Остаточне визначення ризику проводимо 3 урахуванням даних інтраопераційної ревізії та лабораторних досліджень. В експерименті встановлено, що визначення ширини зони розсіювання лазерного променя парієтальною очеревиною дає змогу достовірно визначати наявність перитоніту, його поширеність та диференціювати асептичне i септичне запалення. Дані підтверджені у клінічних спостереженнях, що дало змогу обгрунтовано і вірогідно визначати поширеність ГП.

На другому етапі (під час і після операціі) ми застосовуємо уточнену шкалу. Розмежування груп ризику проводимо так: менше 18 пунктів (C) Гринчук А.Ф., 2019 
звичайний, 18-25 пунктів - збільшений (переважно ранові ускладнення), 26-34 пункти - середній (абсцеси, інфільтрати, дифузний перитоніт, неспроможність швів), більше 35 пунктів - високий ризик (тяжкий перитоніт, сепсис), що підтверджено результатами дисперсійного аналізу. Віднесення конкретного хворого до певної групи ризику дає підставу обгрунтовано використовувати необхідні профілактичні заходи під час операції та в післяопераційний період.

У хворих групи високого ризику вважаємо за доцільне застосовувати розроблений метод пролонгованої санації черевної порожнини. Порівняльний аналіз результатів застосування методу засвідчив прискорення нормалізації фізіологічних функцій, лабораторних показників, зменшення кількості повторних утручань, скорочення термінів лікування. У жодного хворого, яким застосовували дискретну санацію, не було черевних інфільтратів чи залишкових скупчень ексудату, тоді як у $2(20 \%)$ хворих $з$ контрольної групи діагностовано залишкові інтраабдомінальні інфільтрати, що потребувало пролонгованого лікування. Середня тривалість лікування становила $15,25 \pm 1,12$ проти $17,72 \pm 2,71$ днів у групі контролю.

Висновки. 1. Для вірогідного прогнозування ризику післяопераційних ускладнень ефективною $\epsilon$ розроблена шкала, згідно 3 якою оцінювання проводять у два етапи - до та під час операції. 2. Для об'єктивного оцінювання поширеності перитоніту доцільно використовувати розроблений метод, що грунтується на визначенні співвідношення ширини зони розсіювання ураженою і здоровою очеревиною лазерного променя, яке за умов асептичного перитоніту зростає у $1,5-2$ раза, а за септичного перитоніту - більше ніж удвічі. 3 . Запропонована прогностична шкала дає змогу обгрунтовано виділяти групи низького, середнього і високого ризику виникнення післяопераційних ускладнень, а проведення прогнозування в два етапи дає підставу диференційовано застосовувати профілактичні заходи впродовж проведення передопераційного підготування, субопераційно і протягом післяопераційного лікування. 4. Використання розробленого способу пролонгованої санації очеревинної порожнини дає змогу збільшити ефективність лікування, запобігати утворенню інтраабдомінальних запальних інфільтратів і залишкових скупчень ексудату, $i$, як наслідок, істотно скоротити тривалість лікування.

Перспективи подальших досліджень полягають у поглибленому вивченні патогенетичних та розробці на основі отриманих покращених методик його лікування.

\section{Список використаної літератури}

1. Андрющенко ВП, Федоренко СТ, Андрющенко ДВ. Гострий гнійний поширений перитоніт: провідні компоненти сучасної хірургічної тактики. Клін анат та опер хірург. 2012;11(2):91-3.

2. Криворучко ІА, Антонова МС. Ранні та пізні ускладнення при лікуванні хворих на абдомінальний сепсис. Харків хірург школа. 2016;2:56-60.

3. Полянський ІЮ, Гринчук ФВ, Андрієць ВВ, Максим'юк ВВ, Бродовський ВВ, Войтів ЯЮ. Класифікація гострого перитоніту. Клін анат та опер хірург. 2012;11(2):68-70.

4. Germer CT, Eckmann C. Peritonitis. Der Chirurg. 2016;87(1):3-4. doi: 10.1007/s00104-015-0118-5.

5. Baba Guru Prasad N, Bhaskar Reddy KV. A study of acute peritonitis: evaluation of its mortality and morbidity Int Surg J. 2016;3(2):663-668. DOI: 10.18203/2349-2902.isj20161140

6. van Ruler OM, Boermeester A. Surgical treatment of secondary peritonitis A continuing problem. Der Chirurg. 2017;88(1):1-6.

7. Гринчук ФВ. Нова шкала для очінювання коморбідності в невідкладній абдомінальній хірургіï. Art of Medicine. 2018;4(8):55-7.

8. Гринчук АФ. Комплексна діагностика і прогнозування перебігу гострого перитоніту. Art of Medicine. 2018;4(8):52-55.

9. Linder MM, Washa H, Feldmann U. Der Mannheimer Peritonitis-ndex. Chirurg. 1987;58(2):84-92.

\section{References}

1. Andryushchenko VP, Fedorenko ST, Andryushchenko DV. Hostryy hniynyy poshyrenyy perytonit: providni komponenty suchasnoyi khirurhichnoyi taktyky [Acute purulent diffuse peritonitis: the leading components of themodern surgical approach]. Clinical anatomy and operative surgery. 2012;11(2):91-3. (in Ukrainian).

2. Krivoruchko IA, Antonova MS. Ranni ta pizni uskladnennia pry likuvanni khvorykh na abdominalnyi sepsys [Early and late complications in the treatment of patients with abdominal sepsis]. Kharkiv surgical school. 2016;2:56-60. (in Ukrainian).

3. Polyans'kyy IYu, Hrynchuk FV, Andriyets' VV, Maksym'yuk VV, Brodovs'kyy SP, Voytiv YaYu. Klasyfikatsiia hostroho perytonitu [Classification of acute peritonitis]. Clinical anatomy and operative surgery. 
2012;11(2):68-70. doi: https://doi.org/10.24061/165593 (in Ukrainian).

4. Germer CT, Eckmann C. [Peritonitis]. Chirurg. 2016 Jan;87(1):3-4. doi: 10.1007/s00104-015-0118-5. (in German).

5. Baba Guru Prasad N, Bhaskar Reddy KV. A study of acute peritonitis: evaluation of its mortality and morbidity Int Surg J. 2016;3(2):663-8. doi: 10.18203/2349-2902.isj20161140

6. van Ruler OM, Boermeester MA. Surgical treatment of secondary peritonitis : A continuing problem. Chirurg. 2017 Jan;88(Suppl 1):1-6. doi: 10.1007/s00104-015-0121-x.

7. Grynchuk FV. Nova shkala dlia otsiniuvannia komorbidnosti v nevidkladnii abdominalnii khirurhii [New scale for assessing comorbidity in emergency abdominal surgery]. Art of Medicine. 2018;4(8):55-7. (in Ukrainian).

8. Grynchuk AF. Kompleksna diahnostyka i prohnozuvannya perebihu hostroho perytontu [Complex Diagnostics And Acute Peritonitis Prognosis]. Art of Medicine. 2018;4(8):52-55. (in Ukrainian).

9. Linder MM, Washa H, Feldmann U. Der Mannheimer Peritonitis-Index [The Mannheimer peritonitis index]. Chirurg. 1987;58(2):84-92. (in German).

\section{КОМПЛЕКСНЫЙ ПОДХОД К ДИАГНОСТИКЕ И ЛЕЧЕНИЮ ОСТРОГО РАСПРОСТРАНЕН- НОГО ПЕРИТОНИТА}

Резюме. В статье приведены данные по комплексной диагностике и прогнозированию осложнений при остром перитоните, а также метод санации брюшинной полости, основанные на применении наработанных методов. Показано, что определение соотношения ширины зоны рассеивания измененной и неизмененной брюшиной лазерного луча может служить объективным критерием диагностики распространенности перитонита. Приведенная шкала для прогнозирования осложнений при остром перитонита, которая отличается простотой и значительной информативностью и позволяет обоснованно выделять группы низкого, среднего и высокого риска возникновения послеоперационных осложнений, а проведение прогнозирования в два этапа позволяет дифференцированно применять профилактические меры в течение проведения предоперационного подготовки, субоперационное и в течение послеоперационного лечения. Описанный метод санации, который заключается во введении в брюшинную полость багатопросвитного санационно-дренажного устройства, что позволяет значительно улучшить лечение больных острым перитонитом.

Ключевые слова: острый перитонит; диагностика; прогнозирование осложнений; санация; дренажное устройство.

\section{A COMPREHENSIVE APPROACH TO DIAGNOSTICS AND TREATMENT OF ACUTE GENERALIZED PERITONITIS}

Abstract. The article presents the data concerning a comprehensive diagnosis and prognosis of complications in case of acute peritonitis, as well as the method of sanitization of the peritoneal cavity, based on the application of the developed methods. Determination of the ratio of the width of the laser bean scattering zone to the changed and unchanged peritoneum was found to serve as an objective criterion for the diagnosis of the prevalence of peritonitis. The scale to predict complications of acute peritonitis is presented, which is characterized by simplicity and considerable informativity and enables to reasonably differentiate groups of low, medium and high risk of occurrence of postoperative complications, and prognosis in two stages enables to use differential treatment and preventive measures during preoperative preparation, sub-operative and during postoperative treatment. The described method of sanitization, which consists of inserting into the peritoneal cavity of a multi-split sanitation-drainage device, can significantly improve the treatment of patients with acute peritonitis.

Key words: acute peritonitis, diagnostics, prognosis of complications, sanitazation, drainage device.

Відомості про автора

Гринчук Андрій Федорович - аспірант кафедра хірургії №1 Вищого державного навчального закладу України «Буковинський державний медичний університет».

Information about author:

Grynchuk Andrii F. - Postgraduate Department of surgery №1 Higher State Educational Establishment of Ukraine "Bukovinian State Medical University", Chernivtsi. 